\title{
Influence of Nigella sativa and rosemary oils on growth performance, biochemical, antioxidant and immunological parameters, and pathological changes in Japanese quail challenged with Escherichia coli
}

\author{
A.E. Aziza' ${ }^{1,5}$, F.M. Abdelhamid², E.F. Risha ${ }^{2}$, M.M. Elsayed ${ }^{3}$ and W.F. Awadin ${ }^{4}$ \\ Mansoura University, Faculty of Veterinary Medicine, \\ ${ }^{1}$ Nutrition and Nutritional Deficiency Diseases Department, ${ }^{2}$ Clinical Pathology Department, \\ ${ }^{3}$ Hygiene and Zoonoses Department, ${ }^{4}$ Pathology Department, Mansoura 35516, Egypt
}

KEY WORDS: Escherichia coli, essential oils, growth performance, immune response, quails

Received: 19 February 2019

Revised: 9 September 2019

Accepted: 13 December 2019

${ }^{5}$ Corresponding author:

e-mail: aziza_abeer@yahoo.com

\begin{abstract}
The effects of dietary supplementation with rosemary oil (RO), Nigella sativa oil (NSO) and their combination (NSO+RO) were studied in Japanese quails challenged with Escherichia coli. Thirty hundred quail chicks were randomly allocated to 5 equal groups, each of 3 replicates (20 quails/ replicate). Quails in the negative and positive control groups were fed a basal diet based on maize and soybean with vegetable oil as a lipid source. The experimental dietary groups were fed basal diet with RO, NSO or NSO+RO as a lipid source. At day 33 of age, birds from all groups, except negative control, were injected subcutaneously with $200 \mu \mathrm{l}$ of $E$. coli. It was shown that NSO and $\mathrm{NSO}+\mathrm{RO}$ addition significantly improved final body weight and body weight gain in comparison with both control groups. Additionally, the supplementation with RO, NSO or their combination reduced serum liver and kidney functions biomarkers, decreased MDA level and increased antioxidant enzymes activity in both liver and breast muscle in comparison with the positive control. Moreover, serum lysozyme and bactericidal activities were significantly increased in all experimental dietary groups. Furthermore, NSO and NSO+RO treatments suppressed harmful bacteria like E. coli, increased coliforms and lactobacilli bacteria in comparison with the RO group, and also significantly alleviated histopathological and morphometric changes induced by $E$. coli in the small intestine, spleen and bursa of Fabricius. In conclusion, NSO and RO can exert antioxidant and immunomodulatory effects. However, NSO alone or combined with RO is more effective than RO as a growth promoter and for controlling intestinal pathogenic bacteria.
\end{abstract}

\section{Introduction}

In birds Escherichia coli infection causes colibacillosis, a local or systemic disease which in very acute and serious form may lead to septicemia and mortality with heavy economic losses in the poultry industry (Barnes et al., 2008). In broilers $E$. coli infection usually opens a gate for secondary infections with other microorganisms through lowering bird's resistance causing severe illness or death. Moreover, Shen et al. (2010) postulated that E. coli infection may lead to increased lipid peroxidation in cell membranes and may impair antioxidant defence of the body, increase vascular permeability and cause tissue damage. 
Previously, antibiotics at sub-therapeutic levels were used as a growth promoter in the swine and poultry industry as they improve the growth rate and efficiency of feed utilization and reduce morbidity and mortality (Cromwell, 2002). However, the use of antibiotics as feed additives causes an increase in the transmission and proliferation of resistant bacteria via the food chain. This has driven the nutritionists to develop natural products for obtaining the desired weight without the usage of antibiotics as growth promoters.

Recently, growing attention has been paid to essential oils derived from herbs and spices, as an alternative to antimicrobial feed additives, since they exhibit antioxidant, antifungal and digestion-stimulating activities (Hernández et al., 2004). Moreover, plant extracts and essential oils exert effects on different body systems functions, as endocrine and immune ones (Yazan et al., 2009).

One of the historically famous medicinal herb, Nigella sativa (black cumin), belongs to the family Ranunculaceae. Its seeds contain alkaloids, volatile as well as fixed oils and a variety of pharmacologically active substances like thymoquinone, dithymoquinone, carvacrol, thymol, nigellicine$\mathrm{N}$-oxide, nigellidine and $\alpha$-hedrin, which possess activities against a large variety of diseases and are thought to be relatively safe (Nasir et al., 2005). The $N$. sativa seeds contain volatile oils (0.5-1.6\%), fixed oils (35.6-41.6\%), protein and amino acids (22.7\%) (Al-Gaby, 1998). The previous studies reported that fixed oils of $N$. sativa have antibacterial and anti-inflammatory activities, and exert a positive effect on the performance of poultry (Abu-Al-Basal, 2011).

Rosemary (Rosmarinus officinalis) oil is also an essential oil that contains carnosal, carnosic acid, caffeic acid and rosmarinic acid. It has been known that rosemary and its constituents present powerful antioxidant, antibacterial, anti-inflammatory, anticancer, immunomodulatory and health-promoting activities (Al-Kassie et al., 2011). In some studies it was reported that dietary herbal plants or their essential oils improved growth and productive performance (Basmacioğlu et al., 2004), while others had insignificant effects (Abd El-Latif et al., 2013).

Therefore, the current study was designed to evaluate the influence of rosemary oil (RO), $N$. sativa oil (NSO) and their combination on growth performance, biochemical, antioxidant and immunological parameters as well as intestinal bacterial count and histopathological changes in quail chickens challenged with $E$. coli.

\section{Material and methods}

This experiment was approved by the Nutrition and Nutritional Deficiency Diseases Department of the Faculty of Veterinary Medicine, Mansoura University (Egypt). It was conducted at the experimental unit connected to the department. The experimental unit was provided with all equipment necessary to meet the requirements for each experimental group such as light, water and good health condition of the area.

\section{Animals, diets and experimental design}

In total, three hundred 12-day old Japanese quails, of both sex, were randomly divided into five equal groups, each of sixty birds subdivided into three replicates (20 quails/pen). The quails in the negative and positive control groups were fed a maize-soybean basal diet with mixed vegetable oil as a lipid source. The other dietary experimental groups were fed basal diet with rosemary oil (RO), $N$. sativa oil (NSO) or combination of these both oils (NSO+RO) (1 volume: 1 volume) as a lipid source. A 24-h constant lighting program was maintained throughout the experimental period. The composition of diets was adopted from the National Research Council (NRC, 1994), and the ingredients percentage and chemical composition of experimental diets are presented in Table 1.

Table 1. Ingredients and proximate composition of the experimental diets

\begin{tabular}{lc}
\hline Indices & Amount \\
\hline Ingredients \% & \\
maize grain (8.5\%) & 55 \\
soybean meal (44\%) & 35.3 \\
maize gluten (62\%) & 6 \\
oil $^{1}$ & 0.7 \\
limestone $_{\text {dicalcium phosphate }}$ & 1.3 \\
vitamins \& minerals premix & 1 \\
Salt & 0.25 \\
DL-methionine & 0.3 \\
Proximate chemical analysis & 0.1 \\
CP, \% & \\
ME, kcal/kg & 23.98 \\
Ca, \% & 2914 \\
available P, \% & 0.84 \\
\hline
\end{tabular}

${ }^{1}$ mixed vegetable oil in positive or negative control, rosemary oil (RO), Nigella sativa oil (NSO) or their mixture (RO+NSO); ${ }^{2}$ vitamins and minerals premix used to cover the required vitamins and minerals per each kilogram diet (IU: vit. A 10000 , vit. $D_{3}$ 1500; mg: vit. E 10, vit. $K_{3} 2$, vit. $B_{1} 2$, vit. $B_{2} 5$, vit. $B_{6} 3$, vit. $B_{12} 0.01$, niacin 27 , folic acid 1 , biotin 0.05 , pantothenic acid $10, \mathrm{Mn} 60, \mathrm{Zn} 50, \mathrm{Cu} 10$, I 0.1, Se 0.1, Co $0.1, \mathrm{Fe} 50)$; $\mathrm{CP}$ - crude protein, $\mathrm{ME}$ - metabolizable energy 
Rosemary and N. sativa oils were purchased from El-Captain Company (CAPPHARM) for Extracting Natural Herbs and Cosmetics (Cairo, Egypt).

\section{Preparation of $E$. coli suspension and $E$. coli challenge}

A clinical isolate of $E$. coli serogroup $\mathrm{O} 2$ strain from a natural case of poultry colibacillosis was inoculated into Brain Heart Infusion broth (BHI), incubated at $37^{\circ} \mathrm{C}$ for $24 \mathrm{~h}$, and passaged once on Eosin Methylene Blue (EMB) agar for $13 \mathrm{~h}$ at $37^{\circ} \mathrm{C}$. Absorbance was measured with the Nano-Drop 1000 spectrophotometer (Thermo Fisher Scientific, Wilmington, DE, USA) at a wavelength of $600 \mathrm{~nm}$, and the number of bacteria was counted by a standard plate count method. The dose $10^{6}$ colony forming unit (CFU) of $E$. coli per ml was used for experimental reproduction of the disease as reported by Nain and Smits (2011). Before infection, cloacal swabs were collected from all the quails in order to confirm if they were free from pathogenic E. coli organism.

At day 33 of age, quail chickens from all groups, except negative control group, were injected subcutaneously in the breast with $200 \mu \mathrm{l}$ of $1 \times 10^{6} \mathrm{CFU}$ of E. coli serogroup $\mathrm{O} 2$ per $1 \mathrm{ml}$ BHI broth (Lau et al., 2010). Meanwhile, the negative control group was injected subcutaneously with $200 \mu \mathrm{BHI}$ broth per bird.

\section{Growth performance indices of quail chickens}

The quails were weighed individually at the beginning of the experimental period, at day 33 of age and at the end of the experiment (day 40 of age) for the calculation of body weight gain (BWG). The feed conversion rate (FCR) was calculated as $\mathrm{kg}$ feed per $\mathrm{kg}$ BWG. At the end of the trial, all quail chickens were fasted overnight. Two quails per replicate (six birds per treatment) were weighed just prior to slaughter. After removal of feather and evisceration, the heart, liver, gizzard, bursa of Fabricius, thymus and spleen were weighed and expressed as a percentage of body weight (BW).

\section{Sample collection}

At the end of the experiment (day 40 of age), five quails from each treatment were picked up randomly for blood collection. Blood samples were collected from wing vein into plane test tubes and kept at room temperature for 20 min to allow clotting, and then left in the refrigerator for $4 \mathrm{~h}$. Carefully the clear serum was then separated by centrifugation at $3000 \mathrm{rpm}$ for $10 \mathrm{~min}$ and stored at $-20{ }^{\circ} \mathrm{C}$ until further selected biochemical and immunological parameters measurement. After blood sampling birds were slaughtered, and onegram samples from the liver and breast muscle were rapidly excised from each bird, washed in an ice-cold saline buffer $(20 \mathrm{mM}$ Tris-HCl, $0.14 \mathrm{M} \mathrm{NaCl}$ buffer, $\mathrm{pH}$ 7.4) and homogenized in ice-cold phosphatebuffered saline (PBS) ( $\mathrm{pH}$ 7.4). The homogenates were centrifuged at $4{ }^{\circ} \mathrm{C}$ for $15 \mathrm{~min}$ at $3000 \mathrm{rpm}$., the supernatants were then carefully collected and stored at $-80{ }^{\circ} \mathrm{C}$ for estimation of oxidative stress and antioxidant biomarkers (FerdandezBotran et al., 2002). Also, specimen from jejunum, spleen and bursa of Fabricius were fixed in $10 \%$ neutral buffered formalin for histopathological examination.

\section{Serum biochemical analysis}

The serum samples were analysed spectrophotometrically (5010 photometer, BM Co., Berlin, Germany) for estimation of alanine aminotransferase (ALT) and aspartate aminotransferase (AST) activities by using commercial kits provided by Vitro Scient (Hannover, Germany). The serum total protein (TP) and albumin (Alb) contents were evaluated using Stanbio Laboratory (Boerne, TX, USA) kits. Globulin (Glob) concentration in serum was calculated by subtracting albumin from total proteins, after that albumin to globulin ratio (Alb/Glob ratio) was calculated. The creatinine and uric acid contents were assayed by using ready-made kits manufactured by Human (Wiebaden, Germany) and Spinreact (Sant Esteve d'en Bas, Spain), respectively. The kits manufactured by Spinreact (Sant Esteve d'en Bas, Spain) were also used for the determination of cholesterol, triglycerides (TG) and high-density lipoprotein cholesterol (HDL-C) concentrations. Subsequently, very low-density lipoprotein cholesterol (VLDL-C) content was calculated according to Parizdian et al. (2011) by using the following formula: $\mathrm{VLDL}-\mathrm{C}=\mathrm{TG} / 5$.

\section{Oxidative stress and antioxidant markers in tissue homogenates}

The malondialdehyde (MDA) and reduced glutathione (GSH) contents, and catalase (CAT) and superoxide dismutase (SOD) activities were determined in liver and muscle homogenates spectrophotometrically by enzymatic colorimetric method using commercial Bio-diagnostic (Giza, Egypt) kits, according to the supplier's instructions. 


\section{Immunological parameters}

Serum lysozyme activity. Lysozyme activity was measured by the turbidimetric assay as described by Parry et al. (1965). The lysozyme substrate $(0.75 \mathrm{mg} / \mathrm{ml}$ of gram positive bacterium Micrococcus lysodeikticus lyophilized cells) was suspended in $0.1 \mathrm{M}$ sodium phosphate/citric acid buffer of $\mathrm{pH}$ 5.8. Twenty five microliters of serum was added to each well of a round-bottom 96-well microtiter plate with $175 \mu \mathrm{l}$ of substrate solution at $25{ }^{\circ} \mathrm{C}$. By utilizing microtiter plate ELISA reader (RBK 3.500A, Robonik, Brussels, Belgium), the reduction in absorbance was measured after 0 and $20 \mathrm{~min}$ at $450 \mathrm{~nm}$. The unit of lysozyme in serum $(\mu \mathrm{g} / \mathrm{ml})$ was obtained from standard lysozyme curve made with lyophilized hen-egg-white-lysozyme (Sigma-Aldrich, St. Louis, MO, USA).

\section{Serum bactericidal activity}

Serum bactericidal activity was determined according to Kampen et al. (2005). $100 \mu 1$ of serum or Hank's balanced salt solution as control were mixed with $50 \mu \mathrm{l}$ of living 24-h culture of $E$. coli suspension $\left(1 \times 10^{8}\right)$ in a round-bottom 96-well microtiter plate. The plate was then incubated for $2.5 \mathrm{~h}$ at $37{ }^{\circ} \mathrm{C}$. After that, $25 \mu \mathrm{l}$ of diphenyl tetrazolium bromide solution (MTT; $2 \mathrm{mg} / \mathrm{ml}$ ) were added to each well and the plate was then incubated for $10 \mathrm{~min}$ at $25{ }^{\circ} \mathrm{C}$ to allow the development of formazan. The plate was then centrifuged at $2000 \mathrm{~g}$ for $10 \mathrm{~min}$, the supernatant was carefully removed and $200 \mu \mathrm{l}$ of DMSO were added for dissolving formazan. The absorbance of the dissolved formazan was read by microtiter plate ELISA reader (RBK 3.500A, Robonik, Brussels, Belgium) at $560 \mathrm{~nm}$ and was reported as absorbance units by subtracting the absorbance of blank samples.

\section{Microbial populations}

Five quails from each group were sacrificed under aseptic conditions. Liver and intestinal content were taken immediately after the slaughter in screw-capped sterile plastic cups separately. One gram of each liver sample was aseptically added to $9 \mathrm{ml}$ of Tryptic Soya Broth (TSB/CM129, Oxoid, Hants, UK) into a stomacher bag for at least $2 \mathrm{~min}$, and then they were incubated at $37^{\circ} \mathrm{C}$ for $24 \mathrm{~h}$ according to De Boer and Heuvelink (2000). Loopful from the incubated broth was streaked onto the surface of EMB agar (CM69, Oxoid, Hants, UK). After $24 \mathrm{~h}$ at $37^{\circ} \mathrm{C}$, the colonies of E. coli were confirmed biochemically followed by O-serotyping. On the other hand, one gram of intestinal content from each bird was aseptically added to $9 \mathrm{ml}$ of
$0.1 \%$ sterile peptone solution to prepare ten-fold serial dilution up to $10^{7}$ of each sample. Viable counts of total aerobes, coliforms and lactobacilli were performed using the spread-plate technique. Total aerobes were enumerated on nutrient agar (Oxoid, Hants, UK) and coliform enumerated on MacConkey agar, the plates were incubated aerobically at $37^{\circ} \mathrm{C}$ for $24 \mathrm{~h}$. For lactobacilli, deMan, Rogosa and Sharpe (MRS) agar (Biolife, Milan, Italy) was used; the plates were incubated in $5 \% \mathrm{CO}_{2}$ for $48 \mathrm{~h}$. The media plates were inoculated with $0.1 \mathrm{ml}$ of the sample dilutions. After incubation, colonies were counted according to colony morphology. Numbers of CFU per gram of digesta content were recorded (Mahdavi et al., 2010).

\section{Histopathological examination}

Tissue samples from jejunum, spleen and bursa of Fabricius were fixed in $10 \%$ neutral buffered formalin for histopathological study. All fixed tissue samples were embedded in paraffin, sectioned at $5 \mu \mathrm{m}$ and stained with hematoxylin and eosin (H\&E) (Bancroft and Gamble, 2001). The intestinal villus length $(\mu \mathrm{m})$ and width $(\mu \mathrm{m})$ were measured in the jejunum of slaughtered broilers using eyepiece $(10 \times)$ and magnification of $100 \times$ in the microscope according to Sakamoto et al. (2000). Villous surface area $\left(\mu \mathrm{m}^{2}\right)$ was calculated according to the formula: $\pi \times$ villus width $\times$ villus length, as described by Sakamoto et al. (2000). The histological length and width of bursal follicles and white pulps of spleen were measured as mentioned by Khan et al. (2014).

\section{Statistical analysis}

The statistical analysis was conducted by using the statistical software program SPSS for Windows ver. 20 (IBM, Armonk, NY, USA) performing a one-way analysis of variance (ANOVA) with Tukey's post-hoc test. The data were expressed as the mean \pm standard error; values with dissimilar letters are statistically significantly different at $P<0.05$. Graphs were prepared using GraphPad Prism ver. 5 (GraphPad Software Inc., La Jolla, CA, USA).

\section{Results}

Before E. coli infection, there were no significant differences in growth performance among all experimental groups (Table 2). After the challenge, the FBW and BWG of birds fed diets supplemented with $\mathrm{NSO}$ and NSO+RO were significantly increased in comparison with birds from the positive control group. 
Table 2. Impact of rosemary oil (RO), Nigella sativa oil (NSO) or their combination (NSO+RSO) on growth performance of Japanese quails challenged with Escherichia coli

\begin{tabular}{|c|c|c|c|c|c|}
\hline \multirow{2}{*}{ Indices } & \multicolumn{5}{|l|}{ Groups $^{1}$} \\
\hline & negative control & positive control & RO & NSO & $\mathrm{NSO}+\mathrm{RO}$ \\
\hline \multicolumn{6}{|c|}{ Pre-infected, days 12-33 } \\
\hline IW, g & $69.6 \pm 1.7$ & $69.0 \pm 1.2$ & $69.3 \pm 1.5$ & $69.3 \pm 1.4$ & $68.3 \pm 1.5$ \\
\hline BW, g & $180 \pm 2$ & $179 \pm 3$ & $181 \pm 4$ & $178 \pm 2$ & $175 \pm 4$ \\
\hline BWG, g & $110 \pm 2$ & $110 \pm 3$ & $114 \pm 5$ & $112 \pm 3$ & $110 \pm 4$ \\
\hline FCR & $2.71 \pm 0.06$ & $2.69 \pm 0.05$ & $2.75 \pm 0.08$ & $2.65 \pm 0.07$ & $2.64 \pm 0.10$ \\
\hline \multicolumn{6}{|c|}{ Post-infected, days 33-40 } \\
\hline FBW, g & $204 \pm 3^{b}$ & $200 \pm 4^{b}$ & $206 \pm 4^{\mathrm{ab}}$ & $218 \pm 3^{a}$ & $216 \pm 3^{a}$ \\
\hline BWG, g & $137 \pm 3^{b}$ & $135 \pm 3^{b}$ & $141 \pm 4^{b}$ & $154 \pm 3^{a}$ & $152 \pm 3^{a}$ \\
\hline FCR & $3.33 \pm 0.06^{\mathrm{ab}}$ & $3.23 \pm 0.05^{\mathrm{ab}}$ & $3.49 \pm 0.07^{\mathrm{a}}$ & $3.05 \pm 0.05^{b}$ & $3.16 \pm 0.08^{b}$ \\
\hline
\end{tabular}

${ }^{1}$ groups: negative control, positive control, RO, NSO and NSO+RO represent birds fed maize-soybean basal diet with mixed vegetable oil (positive control or negative control), rosemary oil (RO), Nigella sativa oil (NSO) or combination (NSO+RO, 1:1 volume), all groups except negative control were challenged with $E$. coli at day 33 of age; ${ }^{a-b}$ - means with different letters within the same row are significantly different $(P<0.05)$; values are presented as means \pm standard error $(\mathrm{SE})$; IW - initial weight, BW - body weight, BWG - body weight gain, FCR - feed conversion ratio, FBW - final body weight

Carcass and relative organs weight (liver, heart, gizzard, spleen, thymus and bursa of Fabricius) were not considerably affected by any dietary treatment (data not shown).

Escherichia coli infection induced a significant elevation in serum activities of ALT and AST, as well as a serum level of uric acid (Table 3). However, in NSO and NSO+RO supplemented groups these parameters were significantly improved to the level of the negative control group. The ALT activity and uric acid content were also improved by RO supplementation. The serum TP and Glob levels were significantly elevated in NSO group in comparison with the positive control group. Meanwhile, Alb content and $\mathrm{Alb} / \mathrm{Glb}$ ratio were not significantly varied between all experimental groups. Noteworthy, there was observed a serum cholesterol increase in the positive control group in comparison with the negative one. The dietary supplementation of quail diets with RO, NSO or their combination caused non-significantly lower serum cholesterol content than in the positive control group; however cholesterol content in dietary groups did not differ either from positive or negative control groups. In contrast, serum contents of TG and VLDL-C did not differ among all groups. The HDL-C was significantly increased in the RO-treated group as compared with the positive control group

Table 3. Effect of rosemary oil (RO), Nigella sativa oil (NSO) or their combination (NSO+RSO) on the selected serum biochemical parameters in Japanese quails challenged with Escherichia coli

\begin{tabular}{|c|c|c|c|c|c|}
\hline \multirow{2}{*}{ Indices } & \multicolumn{5}{|l|}{ Groups $^{1}$} \\
\hline & negative control & positive control & RO & NSO & $\mathrm{NSO}+\mathrm{RO}$ \\
\hline ALT, U/I & $7.34 \pm 0.57^{b}$ & $12.60 \pm 1.83^{\mathrm{a}}$ & $6.30 \pm 0.54^{b}$ & $5.74 \pm 0.39^{b}$ & $6.16 \pm 0.79^{b}$ \\
\hline AST, U/I & $51.7 \pm 3.1^{\mathrm{b}}$ & $70.5 \pm 6.1^{\mathrm{a}}$ & $57.0 \pm 2.9^{\mathrm{ab}}$ & $54.4 \pm 2.38^{b}$ & $54.5 \pm 2.6^{b}$ \\
\hline Total protein, g/dl & $2.97 \pm 0.17^{b}$ & $2.82 \pm 0.25^{b}$ & $3.94 \pm 0.37^{\mathrm{ab}}$ & $4.95 \pm 0.52^{\mathrm{a}}$ & $4.53 \pm 0.57^{\mathrm{ab}}$ \\
\hline Alb, g/dl & $1.10 \pm 0.07$ & $1.21 \pm 0.08$ & $1.35 \pm 0.17$ & $1.27 \pm 0.05$ & $1.25 \pm 0.09$ \\
\hline Glob, g/dl & $1.86 \pm 0.13^{a b}$ & $1.61 \pm 0.22^{b}$ & $2.59 \pm 0.52^{\mathrm{ab}}$ & $3.67 \pm 0.54^{\mathrm{a}}$ & $3.28 \pm 0.62^{\mathrm{ab}}$ \\
\hline Alb/Glob ratio, \% & $0.60 \pm 0.05$ & $0.82 \pm 0.13$ & $0.71 \pm 0.27$ & $0.38 \pm 0.06$ & $0.46 \pm 0.11$ \\
\hline Creatinine, $\mathrm{mg} / \mathrm{dl}$ & $0.32 \pm 0.02^{\mathrm{ab}}$ & $0.39 \pm 0.01^{a}$ & $0.31 \pm 0.03^{b}$ & $0.33 \pm 0.02^{\mathrm{ab}}$ & $0.34 \pm 0.02^{\mathrm{ab}}$ \\
\hline Uric acid, mg/dl & $2.09 \pm 0.15^{b}$ & $4.01 \pm 0.15^{\mathrm{a}}$ & $2.55 \pm 0.52^{b}$ & $2.91 \pm 0.04^{\mathrm{ab}}$ & $2.46 \pm 0.22^{b}$ \\
\hline Cholesterol, mg/dl & $139 \pm 15^{b}$ & $208 \pm 12^{\mathrm{a}}$ & $159 \pm 9^{\mathrm{ab}}$ & $170 \pm 15^{\mathrm{ab}}$ & $160 \pm 18^{\mathrm{ab}}$ \\
\hline $\mathrm{TG}, \mathrm{mg} / \mathrm{dl}$ & $186 \pm 16$ & $230 \pm 19$ & $233 \pm 15$ & $253 \pm 33$ & $266 \pm 25$ \\
\hline $\mathrm{HDL}-\mathrm{C}, \mathrm{mg} / \mathrm{dl}$ & $66.8 \pm 6.3^{b}$ & $59.7 \pm 7.6^{\mathrm{b}}$ & $99.9 \pm 9.3^{\mathrm{a}}$ & $54.1 \pm 3.7^{\mathrm{b}}$ & $61.6 \pm 2.0^{b}$ \\
\hline VLDL-C, mg/dl & $37.2 \pm 3.1$ & $45.9 \pm 3.7$ & $46.6 \pm 3.1$ & $50.7 \pm 6.6$ & $53.2 \pm 5.0$ \\
\hline
\end{tabular}

${ }^{1}$ groups: negative control, positive control, RO, NSO and NSO+RO represent birds fed maize-soybean basal diet with mixed vegetable oil (positive control or negative control), rosemary oil (RO), Nigella sativa oil (NSO) or combination (NSO+RO, 1:1 volume), all groups except negative control were challenged with $E$. coli at day 33 of age; ${ }^{a-c}$ - means with different letters within the same row are significantly different $(P<0.05)$; values are presented as means \pm standard error (SE); ALT - alanine aminotransferase; AST - aspartate aminotransferase; TP - total protein; Alb - albumin; Glob - globulin; TG - triglyceride; HDL-C - high-density lipoprotein cholesterol; VLDL-C - very low-density lipoprotein cholesterol 
(Table 3). The effects of different dietary treatment on lipid peroxidation and antioxidant enzymes in E. coli challenged quails is illustrated in Figure 1. MDA levels in the liver and breast muscle were significantly reduced to the level in the negative control in all supplemented groups when compared with the positive control group. The hepatic GSH level significantly increased only in RO and NSO groups when compared with both control groups. On the other hand the GSH level in breast muscle was significantly increased in the RO+NSO group as compared with either positive or negative control. CAT activity was significantly increased in the $\mathrm{RO}+\mathrm{NSO}$ group in comparison with the positive control group in both liver and breast muscle. SOD activity in the liver was significantly higher in the $\mathrm{RO}+\mathrm{NSO}$ group compared to the positive control one. Meanwhile, in the breast muscles, SOD activity was significantly higher in the RO group than in the positive control group.
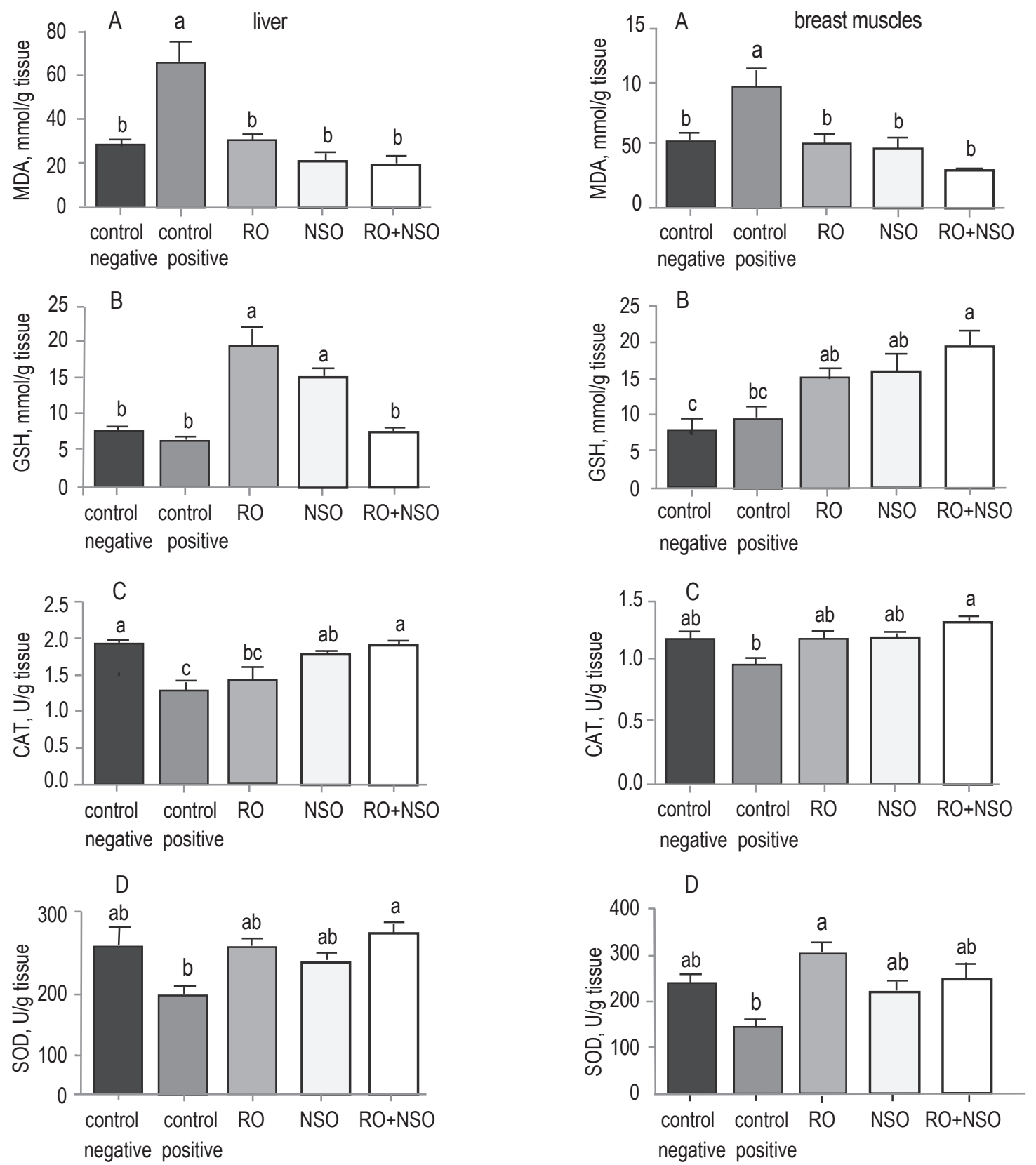

Figure 1. Effect of rosemary oil (RO), Nigella sativa oil (NSO) or their mixture (NSO+RSO) on of dietary supplementation with RO or NSO and their combination on malondialdehyde (MDA) level (A), glutathione (GSH) level (B), catalase (CAT) activity (C) and superoxide dismutase (SOD) activity (D) in Japanese quails challenged with Escherichia coli in (left column) and breast muscles (right column)

Groups: negative control, positive control, RO, NSO and NSO+RO represent birds fed with maize-soybean basal diet with mixed vegetable oil (positive control or negative control), rosemary oil (RO), Nigella sativa oil (NSO) or combination (NSO+RO, 1:1 volume), all groups except negative control were challenged with $E$. coli at day 33 of age; mean \pm standard error; $a-c-$ bars with different letters differ significantly at $P<0.05$ 

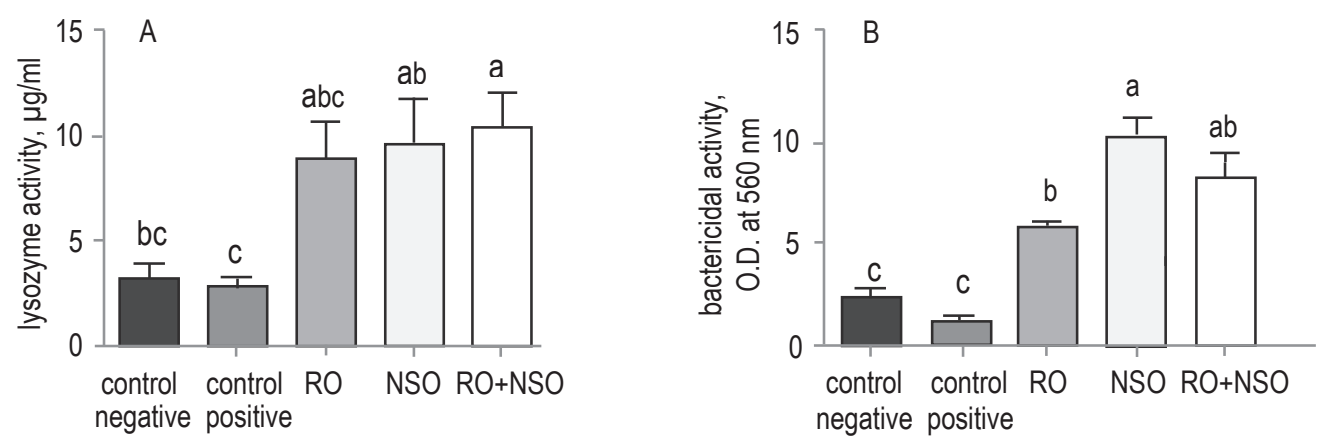

Figure 2. Effect of rosemary oil (RO), Nigella sativa oil (NSO) or their mixture (NSO+RSO) dietary supplementation with RO or NSO and their combination on serum lysozyme activity (A) and bactericidal activity (B) in Japanese quails challenged with Escherichia coli

Groups: negative control, positive control, RO, NSO and NSO+RO represent birds fed with maize-soybean basal diet with mixed vegetable oil (positive control or negative control), rosemary oil (RO), Nigella sativa oil (NSO) or combination (NSO+RO, 1:1 volume), all groups except negative control were challenged with $E$. coli at day 33 of age; mean \pm standard error; a-c-bars with different letters differ significantly at $P<0.05$

Serum lysozyme was significantly elevated in $\mathrm{NSO}$ and RO+NSO groups in comparison with the positive control group. Meanwhile, the bactericidal activity was significantly elevated in all dietary supplemented groups in comparison with both controls (Figure 2).

Quails fed diet supplemented with NSO and $\mathrm{NSO}+\mathrm{RO}$ resisted the $E$. coli infection in comparison with those fed diet with RO. Total aerobic bacterial count in the NSO+RO group was higher than in $\mathrm{RO}$ one; however did not differ from the positive control. Coliforms count was higher in NSO and $\mathrm{NSO}+\mathrm{RO}$ groups in comparison with the RO group; but none of the dietary supplemented groups differ from the positive control. The lactobacilli count was decreased in the RO group in comparison with positive control and NSO and NSO+RO supplemented groups (Table 4).

Microscopical examination of the small intestine in the negative control group showed no histopathological lesions (Figure 3A). The epithelial covering villi and lining the crypts were cuboidal.

Table 4. Effect rosemary oil (RO), Nigella sativa oil (NSO) or their combination (NSO+RSO) on pathogenic Escherichia coli serogroup $\mathrm{O} 2$ strain and intestinal microbial ecology of Japanese quail challenged with Escherichia coli

\begin{tabular}{|c|c|c|c|c|}
\hline \multirow[b]{2}{*}{ Indices } & \multicolumn{4}{|l|}{ Groups 1} \\
\hline & $\begin{array}{l}\text { control } \\
\text { positive }\end{array}$ & RO & NSO & $\mathrm{NSO}+\mathrm{RO}$ \\
\hline $\begin{array}{l}\text { Pathogenic } \\
\text { E. coli }(\mathrm{O} 2)\end{array}$ & + & + & - & - \\
\hline \multicolumn{5}{|c|}{$\begin{array}{l}\text { Total aerobic } \\
\text { bacterial count, } 7.34 \pm 0.24^{\mathrm{ab}} 5.99 \pm 0.30^{\mathrm{b}} 7.95^{\mathrm{a}} \pm 0.42^{\mathrm{ab}} 8.35 \pm 0.34^{\mathrm{a}} \\
\text { CFU } / \mathrm{ml}\end{array}$} \\
\hline $\begin{array}{l}\text { Coliforms, } \\
\text { CFU/ml }\end{array}$ & $5.89 \pm 0.31^{\mathrm{ab}}$ & $\mathrm{ab} 5.34 \pm 0.38^{\mathrm{b}}$ & $7.04 \pm 0.31^{a}$ & $7.26 \pm 0.26^{a}$ \\
\hline $\begin{array}{l}\text { Lactobacilli, } \\
\text { CFU/ml }\end{array}$ & $4.40 \pm 0.27^{a}$ & $2.43 \pm 0.33^{b}$ & $5.12 \pm 0.26^{a}$ & $5.43 \pm 0.18^{a}$ \\
\hline
\end{tabular}

Severe vacuolar degeneration of the epithelial cells in apical halves of the villi was observed in the positive control group (Figure 3B). Loss of apical third of the villi was noticed in the RO group (Figure 3C). Mild epithelial degeneration, loss of tips of the villi and widening of apical lamina propria were observed in NSO and NSO+RO groups (Figures 3D and $3 \mathrm{E}$ ). Morphometric measurements of intestinal villi showed significant variation for villous length among groups. The lowest villous length was in the positive control and the highest in the negative one. The villous length in RO, NSO and NSO+RO groups did not differ but it was higher than in the positive control (Table 5).

Histological examination of the bursa of Fabricius in the negative control group showed no histopathological lesions (Figure 4A). In the positive control group, the follicles became fewer in number and smaller in size than in the negative control group (Figure 4B) accompanied by interstitial oedema and fibrosis. Lymphocytic depletion in follicles was observed where lymphocytes were replaced by vacuoles (Figure 4C). In three dietary treated groups, these changes were milder than in the positive control group (Figures 4D-F). The follicles became larger with less interstitial fibrosis in the NSO+RO group (Figure 4F). Follicular length and width did not differ among all groups (Table 5).

The microscopical examination of spleen in the negative control group showed no histopathological lesions (Figure 5A). In the positive control group, lymphocytes were depleted from the white pulp (Figure 5B). In three dietary-treated groups, the lymphocytic population in white pulp was restored (Figure 5C-E). Morphometric measurements of white pulp length and width showed significant variation in length with statistical difference only between negative control and NSO+RO group (Table 5). 

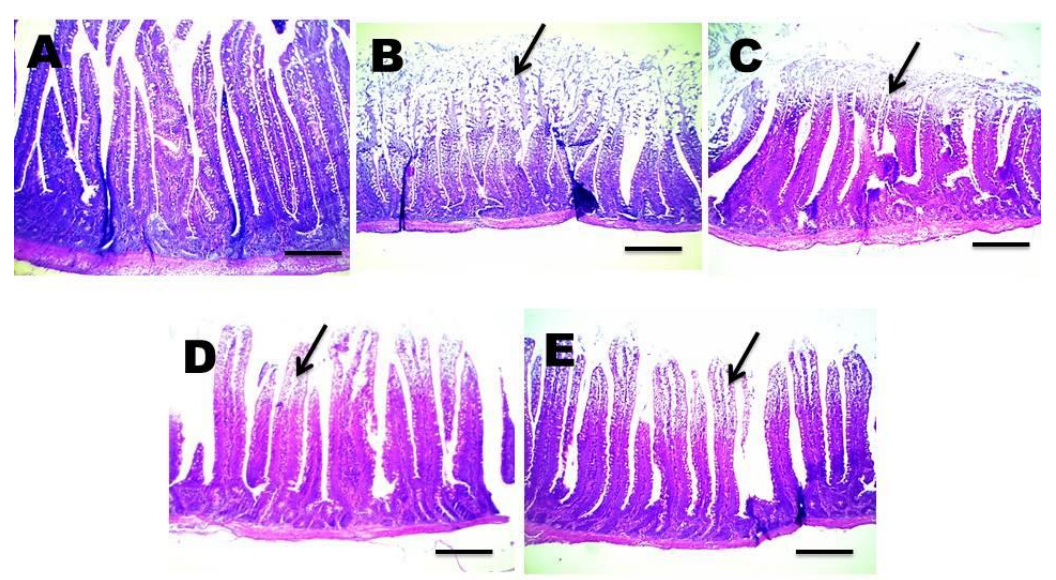

Figure 3. Jejunum showing normal villi covered with cuboidal epithelium in control negative group (A), severe vacuolar degeneration of the epithelial cells covering villi (arrow) in apical halves of the villi in control positive group (arrow) (B), loss of apical third of the villi in RO supplemented group (arrow) (C), mild epithelial degeneration, loss of tips of the villi and widening of apical lamina propria in NSO and NSO+RO supplemented groups (arrow) (D and $E$, respectively)

Groups: negative control, positive control, RO, NSO and NSO+RO represent birds fed maize-soybean basal diet with mixed vegetable oil (positive control or negative control), rosemary oil (RO), Nigella sativa oil (NSO) or combination (NSO+RO, 1:1 volume), all groups except negative control were challenged with $E$. coli at day 33 of age; hematoxylin and eosin stain; $A-E$ : $100 \times$ magnification, bar $=100$
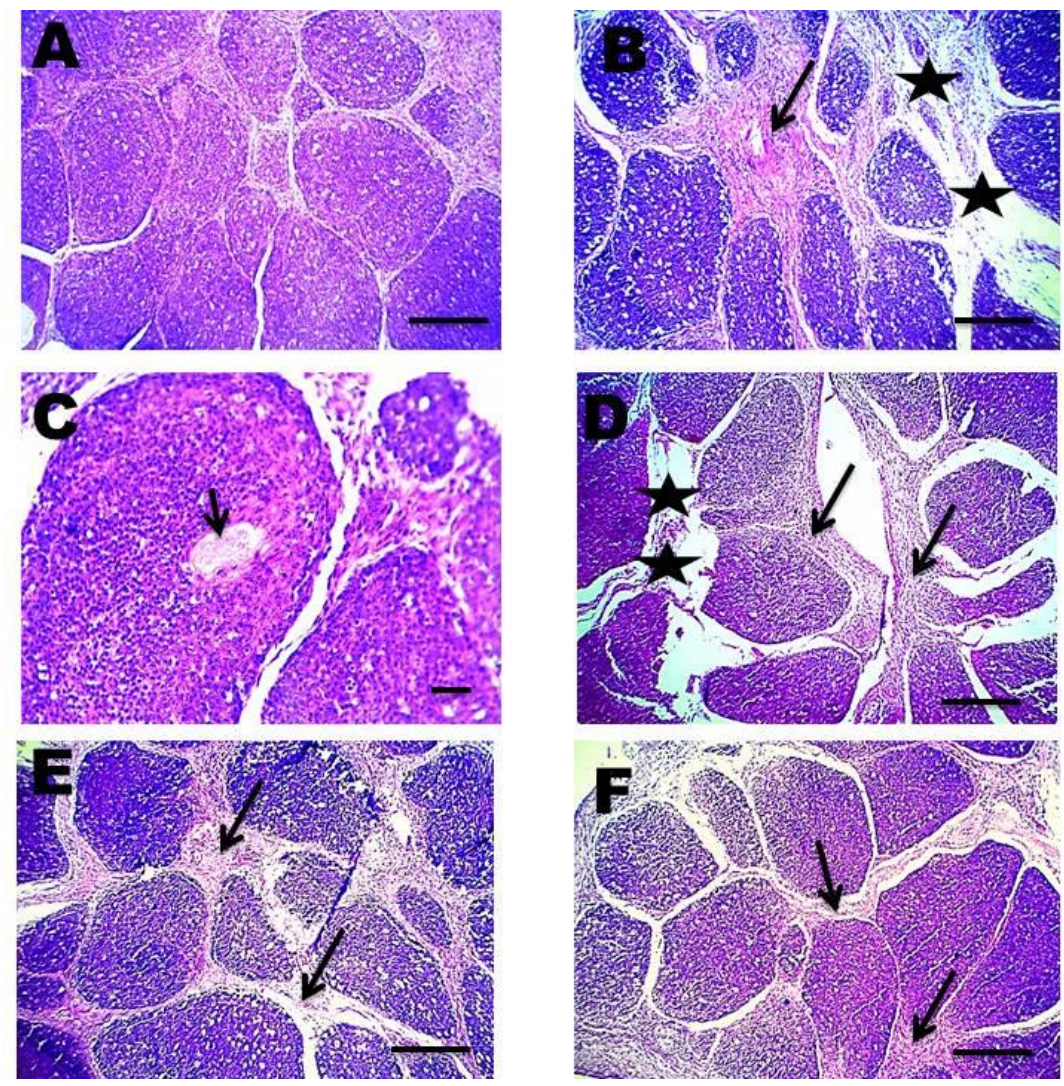

Figure 4. Bursa of Fabricius showing normal histology in control negative group (A) and fewer and smaller follicles in control positive group (B), besides, oedema (asterisk) and fibrosis (arrow) in the interfollicular interstitium (B), lymphocytic depletion of lymphocytes which was replaced by vacuole (small arrow) (C), interstitial oedema (asterisks) and fibrosis (arrows) in RO group (D), less interstitial fibrosis (arrows) in NSO and $\mathrm{NSO}+\mathrm{RO}$ groups ( $\mathrm{E}$ and $\mathrm{F}$, respectively). Note: size of follicles became larger than in control positive group $(\mathrm{F})$

Groups: negative control, positive control, RO, NSO and NSO+RO represent birds fed maize-soybean basal diet with mixed vegetable oil (positive control or negative control), rosemary oil (RO), Nigella sativa oil (NSO) or combination (NSO+RO, 1:1 volume), all groups except negative control were challenged with $\mathrm{E}$. coli at day 33 of age; hematoxylin and eosin stain; A-F: 100x magnification, except C: 200x; bar = 100, except C = 50 

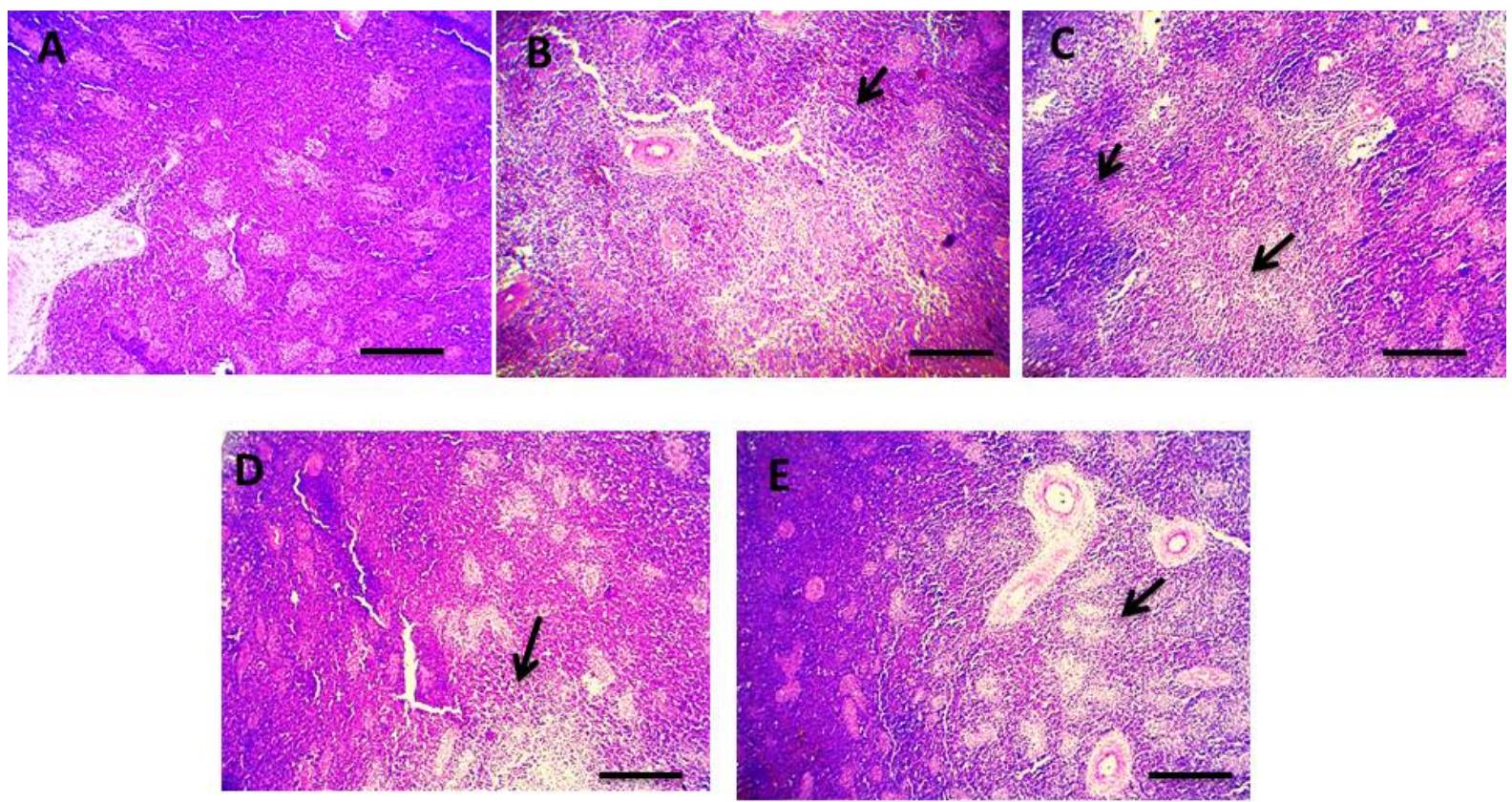

Figure 5. Spleen showing normal histology in control negative group (A) and marked lymphocytic depletion (pointed with arrows) of white pulp in control positive group (B). Lymphocytic population gradually restored in RO (C), NSO (D), NSO+RO (E) groups

Groups: negative control, positive control, RO, NSO and NSO+RO represent birds fed maize-soybean basal diet with mixed vegetable oil (positive control or negative control), rosemary oil (RO), Nigella sativa oil (NSO) or combination (NSO+RO, 1:1 volume), all groups except negative control were challenged with $E$. coli at day 33 of age; hematoxylin and eosin stain; A-E: $100 \times$ magnification, bar $=100$

Table 5. Impact of rosemary oil (RO), Nigella sativa oil (NSO) or their combination (NSO+RSO) on morphometric parameters in intestine, bursa of Fabricius and spleen of Japanese quails challenged with Escherichia coli

\begin{tabular}{|c|c|c|c|c|c|}
\hline \multirow{2}{*}{$\begin{array}{l}\text { Morphometric } \\
\text { parameters }\end{array}$} & \multicolumn{5}{|l|}{ Groups $^{1}$} \\
\hline & negative control & positive control & $\mathrm{RO}$ & NSO & $\mathrm{NSO}+\mathrm{RO}$ \\
\hline \multicolumn{6}{|l|}{ Intestinal villi } \\
\hline length, $\mu \mathrm{m}$ & $1165 \pm 38^{a}$ & $570 \pm 18^{c}$ & $767 \pm 33^{b}$ & $885 \pm 38^{b}$ & $893 \pm 30^{b}$ \\
\hline width, $\mu \mathrm{m}$ & $76.2 \pm 8.1$ & $72.4 \pm 8.6$ & $114.0 \pm 18.5$ & $79.6 \pm 17.2$ & $84.6 \pm 17.2$ \\
\hline surface area, $\mu \mathrm{m}^{2}$ & $282452 \pm 37955$ & $129033 \pm 13744$ & $277764 \pm 53738$ & $228170 \pm 60574$ & $235719 \pm 45675$ \\
\hline \multicolumn{6}{|l|}{ Bursal follicles } \\
\hline length, $\mu \mathrm{m}$ & $639 \pm 30$ & $568 \pm 33$ & $587 \pm 46$ & $603 \pm 50$ & $604 \pm 78$ \\
\hline width, $\mu \mathrm{m}$ & $479 \pm 70$ & $444 \pm 40$ & $458 \pm 31$ & $459 \pm 36$ & $460 \pm 12$ \\
\hline \multicolumn{6}{|l|}{ Splenic white pulp } \\
\hline length, $\mu \mathrm{m}$ & $399 \pm 21^{\mathrm{ab}}$ & $298 \pm 18^{b}$ & $350 \pm 15^{\mathrm{ab}}$ & $436 \pm 54^{a}$ & $374 \pm 14.65^{a b}$ \\
\hline width, $\mu \mathrm{m}$ & $262 \pm 28$ & $241 \pm 35$ & $265 \pm 26$ & $345 \pm 27$ & $302 \pm 13.2$ \\
\hline
\end{tabular}

${ }^{1}$ groups: negative control, positive control, RO, NSO and NSO+RO represent birds fed with maize-soybean basal diet with mixed vegetable oil (positive control or negative control), rosemary oil (RO), Nigella sativa oil (NSO) or combination (NSO+RO, 1:1 volume), all groups except negative control were challenged with $E$. coli at day 33 of age; ${ }^{a-b}$ - means with different letters within the same row are significantly different $(P<0.05)$; values are presented as means \pm standard error (SE)

\section{Discussion}

Currently, the usage of essential oil mixtures as feed additives in poultry nutrition has gained great interest, especially after the ban on using antibiotics. Previously, several studies have evaluated the effect of essential oils supplementation on growth performance, antimicrobial and antioxidant activities as well as nutrient digestibility and lipid me- tabolism (Al Saleh et al., 2006; Abd El-Hack and Alagawany, 2015; Attia and Al-Harthi 2015; Torki et al., 2018). Herein, $N$. sativa oil either separately or in the combination with rosemary oil has a positive effect on growth performance rather than rosemary oil alone. That could be related to $N$. sativa oil high nutritive value, as it contains a mixture of beneficial fatty acids such as linoleic, linolenic and oleic acids (Babayan et al., 1978). 
Also, it exerts choleric effects increasing bile flow, which acts as an emulsifying agent, as well as it activates the pancreatic lipase which aids fat digestion and fat-soluble vitamins absorption (Crossland, 1980). In addition, NSO stimulates the digestive enzymes in the intestinal mucosa and pancreas, so improves the digestion of dietary nutrients and feed efficiency (Abu-Dieyeh and Abu-Darwish, 2008). The results obtained in the present study are in line with the findings of Saleh (2014) and Attia and Al-Harthi (2015) who recorded that feed intake, BWG and FCR were improved by $N$. sativa supplementation. However, NSO and RO had no effect on carcass and relative organs weight as mentioned by Toghyani et al. (2010) and Abd El-Latif et al. (2013).

The analysis of serum biochemical parameters gives an indication about the health, nutritional and physiological status of animals (Abd El-Hack and Alagawany, 2015). In this study, the results of serum of liver and kidney function biomarkers, and TP and Glob levels were in agreement with the results of Khan et al. (2012), Soliman et al. (2017) and El-Hack et al. (2018). The increase in serum TP may be referred to the immunostimulant effect of N. sativa (Al-Beitawi and El-Ghousein, 2008) and the availability of black cumin seed proteins in birds diets (Khan et al., 2012). In the same context, Yildirim et al. (2018) found that diet supplemented with ethanolic extract of rosemary (Rosmarinus officinalis) (100 and $200 \mathrm{mg} / \mathrm{kg}$ basal diet) in broilers for 42 days significantly reduced serum ALT and AST activities but had no effect on Alb and Alb/Glob ratio. Additionally, serum levels of TP, Alb, Glob and $\mathrm{Alb} / \mathrm{Glob}$ ratio did not differ in broiler supplemented with RO at a dose 100 and $200 \mathrm{mg} / \mathrm{kg}$ diet (Abd El-Latif et al., 2013). Furthermore, the serum creatinine level was significantly improved in sodium nitrate intoxicated birds treated with rosemary extract (Akhavast and Daneshyar, 2017).

The hepatoprotective effect of black cumin is related to its components, particularly thymoquinone, carvacrol, p-cymene, m-cymene and $\alpha$-thujene, which have antioxidant and free radicals scavenging properties, subsequently inhibiting lipid peroxidation (Hassan et al., 2012).

In the present study, the RO supplementation non-significantly reduced the serum the cholesterol level that may be caused by the inhibition of hepatic 3-hydroxy-3-methylglutaryl coenzyme A (HMG-CoA) reductase activity that is necessary for cholesterol synthesis (Valenzuela et al., 2004). This is proven by the previous study of Alagawany and ElHack (2015) who reported a decrease in serum TG, cholesterol and LDL-C content, but an increase in HDL-C content in laying hen with rosemary dietary treatment. Partially in accordance with the present study, Torki et al. (2018) reported a significant reduction in the serum cholesterol level in laying hen fed diet supplemented with $200 \mathrm{mg}$ RO per kg diet. Conversely, Abd El-Latif et al. (2013) found that TG, TC, LDL-C and HDL-C were significantly increased in broiler fed diet supplemented with RO and such discrepancy may be attributed to breed, gender, age, feed composition, route of administration and experimental conditions.

Nigella sativa oil alone or combined with RO had no effect on serum cholesterol and HDL-C levels, which is in agreement with Khalaji et al. (2011) who found no effect of black cumin on serum levels of cholesterol, TG, HDL-C and VLDL-C. In contrast, Shokrollahi and Sharifi (2018) reported hypocholesterolemic effect of $N$. sativia, which may be attributed to its component such as thymoquinone and monounsaturated fatty acids (MUFA) that may lower either synthesis of cholesterol by hepatocytes or its reabsorption from small intestine and increase its conversion to bile acids (Khodary et al., 1996; Brunton, 1999). Black cumin has also inhibitory effects on HMG-CoA reductase activity (Khan et al., 2012).

The dietary supplementation with RO, NSO or their combination significantly reduced MDA level and increased antioxidant enzymes activities. The antioxidant activity of rosemary may be attributed to its components such as phenolic diterpenes, flavonoids, phenolic acids and volatile oils which have free radical scavenging properties (Ho et al., 2000; Begum et al., 2013). The role of RO in reducing MDA and increasing GSH level and CAT activity was previously reported by Türk et al. (2016) and Yildirim et al. (2018). Black cumin may be an antioxidant that inhibits free radicle production and increases antioxidant enzymes activity due to the main bioactive components of black cumin essential oil (Tülüce et al., 2009). Such a result is in agreement with El-Hack et al. (2018). The anti-inflammatory effect of polyphenol containing substances may cause inhibition of nuclear factor kappa (NF- $\kappa \mathrm{B})$ signalling consequently enhancing nuclear factor erythroid 2-related factor $2(\mathrm{Nrf} 2)$ activation, which protects cells against oxidative damage and stimulates antioxidant activity (Tangney and Rasmussen, 2013).

Serum lysozyme and bactericidal activities were improved in all supplemented groups. Few previous studies stated that medicinal plants 
and their constituent could activate immune functions, e.g., rosemary powder inoculated to the diet of laying hen (3, 6 and $9 \mathrm{~g} / \mathrm{kg}$ diet) improved serum immunoglobulin (Ig) M content (Alagawany et al., 2015). Additionally, RO significantly increased phagocytic activity and phagocytic index in broilers (Abd El-Latif et al., 2013). Moreover, black cumin may have an immunostimulant effect by increasing antibody titer against Newcastle disease (ND) and infectious Bursal disease as well as IgG and IgA contents in broilers challenged with $E$. coli and fed 4.2 or $5.6 \%$ N. sativa (Soliman et al., 2017).

Nigella sativa has beneficial effects on the immunity and growth performance that may be related to its antimicrobial, antioxidant and antiinflammatory activities (Al Saleh et al., 2006). It has also an effect on intestinal microflora that has a vital role in the health status of host animals (Guo et al., 2004). In the present study, the better improvement in microflora was stated in NSO and $\mathrm{NSO}+\mathrm{RO}$ groups than in RO. Since the number of useful bacteria increased in order to inhibit the colonization of invading pathogens maintaining the host health. Antimicrobial activity of NSO is closely linked with its constituents especially polyphenols and volatile oils which have pharmacological effects against, e.g. Staphylococcus and E. coli (Ishtiaq et al., 2013; Gessner et al., 2017). It was hypothesized that essential oils can destabilize mitochondrial membranes and disturb the cellular integrity of both prokaryotic and eukaryotic cells resulting in cell death via necrosis and apoptosis (Bakkali et al., 2007).

Moreover, it has been observed that RO has no significant effect on E. coli counts. Norouzi et al. (2015) showed a significant elevation in E. coli counts in broiler chickens parallel with increasing rosemary supplementation. Otherwise, Cross et al. (2007) found no significant effects of rosemary supplementation on lactic acid bacteria or coliform counts. However, Al-Kassie et al. (2008) showed that lactobacilli counts increased and coliform counts decreased with increasing level of rosemary supplementation in broiler diet from 0.5 to $1 \%$.

In the present study dietary treatments alleviated histopathological and morphometric changes induced by $E$. coli in small intestine, spleen and bursa of Fabricius. The non-significant increases in relative weights of lymphoid organs supported by the restored histopathological pictures observed in the bursa of Fabricius and spleen were indicative of better immune response and good physiological status of birds. The performance and feed efficiency were in turn closely interrelated with the qualitative and quantitative microbial load of the animal gut, the morphological structure of the intestinal wall and the activity of the immune system. Finally, most of the above-mentioned improvement effects were observed in NSO+RO and NSO groups. This may be returned to thymoquinone the most active component of NSO that exhibits potent antioxidative, anti-inflammatory and antibacterial effects.

\section{Conclusions}

Both rosemary oil (RO) and Nigella sativa oil (NSO) can exert hepato-renal protective, antioxidant and immunomodulatory effects. Moreover, NSO alone or in the combined treatment with RO improved performance, histology of villi and immune-related organs, and exerted more beneficial effects on intestinal microflora in quails challenged with E. coli. Thus, $\mathrm{NSO}$ and NSO+RO could be used either as growth promoters or as a tool for controlling intestinal pathogenic bacteria.

\section{Acknowledgment}

The authors wish to acknowledge the departments of Nutrition and Nutritional Deficiency Diseases, Clinical Pathology, and Pathology for their help and encouragement during the course of this study.

\section{References}

Abd El-Hack M.E., Alagawany M., 2015. Performance, egg quality, blood profile, immune function, and antioxidant enzyme activities in laying hens fed diets with thyme powder. J. Anim. Feed Sci. 24, 127-133, https://doi.org/10.22358/ jafs/65638/2015

Abd El-Latif A.S., Saleh N.S., Allam T.S., Ghazy E.W., 2013. The effects of rosemary (Rosemarinus afficinalis) and garlic (Allium sativum) essential oils on performance, hematological, biochemical and immunological parameters of broiler chickens. Br. J. Poult. Sci. 2, 16-24, https://doi.org/10.5829/idosi.bjps.2013.2.2.74145

Abu-Al-Basal M.A., 2011. Influence of Nigella sativa fixed oil on some blood parameters and histopathology of skin in Staphylococcal-infected BALB/c mice. Pak. J. Biol. Sci. 14, 1038-1046, https://doi.org/10.3923/pjbs.2011.1038.1046

Abu-Dieyeh Z.H.M., Abu-Darwish M.S., 2008. Effect of feeding powdered black cumin seeds (Nigella sativa L.) on growth performance of 4-8 week-old broilers. J. Anim. Vet. Adv. 7, 292-296

Akhavast A.R., Daneshyar M., 2017. Effects of rosemary (Rosmarinus officinalis) extract on performance, antioxidant ability and blood gas indices of broiler chickens treated with sodium nitrate in drinking water. Iran. J. Appl. Anim. Sci. 7, 471-477 
Alagawany M., Farag M.R., Dhama K., 2015. Nutritional and biological effects of turmeric (Curcuma longa) supplementation on performance, serum biochemical parameters and oxidative status of broiler chicks exposed to endosulfan in the diets. Asian J. Anim. Vet. Adv. 10, 86-96, https://doi.org/10.3923/ ajava.2015.86.96

Alagawany M., Abd El-Hack M.E., 2015. The effect of rosemary herb as a dietary supplement on performance, egg quality, serum biochemical parameters, and oxidative status in laying hens. J. Anim. Feed Sci. 24, 341-347, https://doi.org/10.22358/ jafs/65617/2015

AL-Beitawi N., El-Ghousein S.S., 2008. Effect of feeding different levels of Nigella sativa seeds (black cumin) on performance, blood constituents and carcass characteristics of broiler chicks. Int. J. Poult. Sci. 7, 715-721, https://doi.org/10.3923/ ijps.2008.715.721

Al-Gaby A.M.A., 1998. Amino acid composition and biological effects of supplementing broad bean and corn proteins with Nigella sativa (black cumin) cake protein. Nahrung 42, 290-294, https://doi.org/10.1002/(SICI)15213803(199810)42:05<290::AID-FOOD290>3.0.CO;2-Y

Al-Kassie G.A.M., Mohammed M.F., Hamood M.F., Jameel Y.J., 2008. The effect of anise and rosemary on the microbial balance in gastro intestinal tract for broiler chicks. Int. J. Poultry Sci. 7 , 610-612, https://doi.org/10.3923/ijps.2008.610.612

Al-Kassie G.A.M., Abd-Al-Jaleel R.A., Mohseen A.M., 2011. The effect of a mixture of anise and rosemary on broiler performance. Agric. Biol. J. N. Am. 2, 1279-1282, https://doi.org/10.5251/ abjna.2011.2.9.1279.1282

Al Saleh I.A., Billedo G., El-Doush I.I., 2006. Level of selenium, DL-atocopherol, DL- $\gamma$ - tocopherol, all-trans-retinol, thymoquinone and thymol in different brands of Nigella sativa seeds. J. Food Comp. Anal. 19, 167-175, https://doi.org/10.1016/j. jfca.2005.04.011

Attia Y.A., Al-Harthi M.A., 2015. Nigella seed oil as an alternative to antibiotic growth promoters for broiler chickens. Eur. Poult. Sci. 2015, article ID 79, https://doi.org/10.1399/eps.2015.80

Babayan V.K., Koottungal D., Halaby G.A., 1978. Proximate analysis, fatty acid composition of Nigella sativa L. seeds. J. Food Sci. 43, 1314-1315, https://doi. org/10.1111/j.1365-2621.1978.tb15297.x

Bakkali F., Averbeck S., Averbeck D., Idaomar M., 2008. Biological effects of essential oils. Food Chem. Toxicol. 46, 446-475, https://doi.org/10.1016/j.fct.2007.09.106

Bancroft J.D., Gamble M. (Editors), 2001. Theory and Practice of Histological Techniques. $5^{\text {th }}$ Edition. Churchill Livingstone. London (UK), pp. 125-138

Barnes J.H., Nolan L.K., Vaillancourt J.-P., 2008. Colibacillosis. In: Y.M. Saif (Editor). Diseases of Poultry. 12 ${ }^{\text {th }}$ Edition. Blackwell Publishing Professional. Ames, IA (USA), pp. 691-732

Basmacıoğlu H., Tokuşoğlu Ö., Ergül M., 2004. The effect of oregano and rosemary essential oils or a-tocopheryl acetate on performance and lipid oxidation of meat enriched with n-3 PUFA's in broilers. S. Afr. J. Anim. Sci. 34, 197-210

Begum A., Sandhya S., Shaffath Ali S.S., Vinod K.R., Reddy S., Banji D., 2013. An in-depth review on the medicinal flora Rosmarinus officinalis (Lamiaceae). Acta Sci. Pol. Technol. Aliment. 12, 61-73

Brunton L.L., 1999. Agents affecting gastrointestinal water flux and motility, digestants and bile acids. In: A.G. Gilman, T.W. Rall, A.S. Nies, P. Taylor (Ediotrs). The Pharmacological Basis of Therapeutic. $8^{\text {th }}$ Edition. Pergamon Press. New York, NY (USA), pp. 914-932
Cromwell G.L., 2002. Why and how antibiotics are used in swine production. Anim. Biotechnol. 13, 7-27, https://doi.org/10.1081/ ABIO-120005767

Cross D.E., McDevitt R.M., Hillman K., Acamovic T., 2007. The effect of herbs and their associated essential oils on performance, dietary digestibility and gut microflora in chickens from 7 to 28 days of age. Br. Poult. Sci. 48, 496-506, https://doi. org/10.1080/00071660701463221

Crossland J., 1980. Lewiss Pharmacology. $5^{\text {th }}$ Edition. Churchill Livingston. London (UK), pp. 656-657

De Boer E., Heuvelink A.E., 2000. Methods for the detection and isolation of Shiga toxin-producing E. coli. J. Appl. Microbiol. 88, S1, 133-143, https://doi.org/10.1111/j.1365-2672.2000. tb05341.x

El-Hack M.E.A., Mahgoub S.A., Hussein M.M.A., Saadeldin I.M., 2018. Improving growth performance and health status of meat-type quail by supplementing the diet with black cumin cold-pressed oil as a natural alternative for antibiotics. Environm. Sci. Pollut. Res. 25, 1157-1167, https://doi. org/10.1007/s11356-017-0514-0

Ferdandez-Botran R., Gorantla V., Sun X.C. et al., 2002. Targeting of glycosaminoglycan-cytokine interactions as a novel therapeutic approach in allotransplantation. Transplantation 74, 623-629, https://doi.org/10.1097/00007890-20020915000007

Friedewald W.T., Levy R.I., Fredrickson D.S., 1972. Estimation of the concentration of low-density lipoprotein cholesterol in plasma, without use of the preparative ultracentrifuge. Clin. Chem. 18, 499-502

Gessner D.K., Ringseis R., Eder K., 2017. Potential of plant polyphenols to combat oxidative stress and inflammatory processes in farm animals. J. Anim. Physiol. Anim. Nutr. 101, 605-628, https://doi.org/10.1111/jpn.12579

Guo F.C., Williams B.A., Kwakkel R.P., Li H.S., Li X.P., Luo J.Y., Li W.K., Verstegen M.W.A., 2004. Effects of mushroom and herb polysaccharides, as alternatives for an antibiotic, on the cecal microbial ecosystem in broiler chickens. Poult. Sci. 83, 175-182, https://doi.org/10.1093/ps/83.2.175

Hassan A.S., Ahmed J.H., Al-Haroon S.S., 2012. A study of the effect of Nigella sativa (Black seeds) in isoniazid (INH)-induced hepatotoxicity in rabbits. Ind. J. Pharmacol. 44, 678-682, https://doi.org/10.4103/0253-7613.103239

Hernández F., Madrid J., García V., Orengo J., Megías M.D., 2004. Influence of two plant extracts on broilers performance, digestibility and digestive organ size. Poult. Sci. 83, 169-174, https://doi.org/10.1093/ps/83.2.169

Ho C.-T., Wang M., Wei G.-J., Huang T.-C., Huang M.-T., 2000. Chemistry and antioxidative factors in rosemary and sage. Biofactors 13, 161-166, https://doi.org/10.1002/biof.5520130126

Ishtiaq S., Ashraf M., Hayat M.Q., Asrar M., 2013. Phytochemical analysis of Nigella sativa and its antibacterial activity against clinical isolates identified by ribotyping. Int. J. Agric. Biol. 15, $1151-1156$

Kampen A.H., Tollersrud T., Lund A., 2005. Staphylococcus aureus capsular polysaccharide types 5 and 8 reduce killing in bovine neutrophils in vitro. Infect. Immun. 73, 1578-1583, https://doi. org/10.1128/IAI.73.3.1578-1583.2005

Khalaji S., Zaghari M., Hatami K.H., Hedari-Dastjerdi S., Lotfi L., Nazarian H., 2011. Black cumin seeds, Artemisia leaves (Artemisia sieberi), and Camellia L. plant extract as phytogenic products in broiler diets and their effects on performance, blood constituents, immunity, and cecal microbial population. Poult. Sci. 90, 2500-2510, https://doi.org/10.3382/ps.2011-01393 
Khan S.H., Ansari J., Haq A.U., Abbas G., 2012. Black cumin seeds as phytogenic product in broiler diets and its effects on performance, blood constituents, immunity and caecal microbial population. Ital. J. Anim. Sci. 11, article ID e77, https://doi. org/10.4081/ijas.2012.e77

Khan M.Z.I., Masum A., Khan M.Z.I., Aziz A.R.B., Nasrin M., Siddiqi M.N.H., Arshad M.M.B., 2014. Histomorphology of the lymphoid tissues of broiler chickens in Kelantan, Malaysia. Sains Malaysiana 43, 1175-1179

Khodary R.M., El-Azzawy M.H., Hamdy I.R., 1996. Effect of Nigella sativa on egg production hatchability percentage and some biochemical values in laying hens with reference to fertility in cockerels. In: $7^{\text {th }}$ Scientific Congress, Faculty of Veterinary Medicine, 17-19 November 1996. Assiut (Egypt)

Lau G.L., Sieo C.C., Tan W.S., Hair-Bejo M., Jalila A., Ho Y.W., 2010. Efficacy of a bacteriophage isolated from chickens as a therapeutic agent for colibacillosis in broiler chickens. Poult. Sci. 89, 2589-2596, https://doi.org/10.3382/ps.2010-00904

Mahdavi A.H., Rahmani H.R., Nili N., Samie A.H., Soleimanian-Zad S., Jahanian R., 2010. Effects of dietary egg yolk antibody powder on growth performance, intestinal Escherichia coll colonization, and immunocompetence of challenged broiler chicks. Poult. Sci. 89, 484-494, https://doi.org/10.3382/ ps.2009-00541

Nain S., Smits J.E.G., 2011. Validation of a disease model in Japanese quail (Coturnix coturnix japonica) with the use of Escherichia coli serogroup $\mathrm{O} 2$ isolated from a turkey. Can. J. Vet. Res. 75, $171-175$

NRC (National Research Council), 1994. Nutrient Requirements of Poultry. $9^{\text {th }}$ Revised Edition. The National Academies Press. Washington, DC (USA), https://doi.org/10.17226/2114

Nasir Z., Abid A.R., Hayat Z., Shakoor H.I., 2005. Effect of kalongi (Nigella sativa) seeds on egg production and quality in white Leghorn layers. J. Anim. Plant. Sci. 15, 22-24

Norouzi B., Qotbi A.A.A., Seidavi A., Schiavone A., Marín A.L.M., 2015. Effect of different dietary levels of rosemary (Rosmarinus officinalis) and yarrow (Achillea millefolium) on the growth performance, carcass traits and ileal microbiota of broilers. Ital. J. Anim. Sci. 14, 3930, https://doi.org/10.4081/ijas.2015.3930

Parizadian B., Shams-shargh M., Zerehdaran S., 2011. Study the effects of different levels of energy and L-carnitine on meat quality and serum lipids of Japanese quail. Asian J. Anim. Vet. Adv. 6, 944-952, https://doi.org/10.3923/ajava.2011.944.952

Parry R.M., Chandan R.C., Shahani K.M., 1965. A rapid and sensitive assay of muramidase. Proceed. Soc. Exp. Biol. Med. 119, 384-386, https://doi.org/10.3181/00379727-119-30188

Sakamoto K., Hirose H., Onizuka A., Hayashi M., Futamura N., Kawamura Y., Ezaki T., 2000. Quantitative study of changes in intestinal morphology and mucus gel on total parenteral nutrition in rats. J. Surg. Res. 94, 99-106, https://doi. org/10.1006/jsre.2000.5937
Saleh A.A., 2014. Nigella seed oil as alternative to avilamycin antibiotic in broiler chicken diets. S. Afr. J. Anim. Sci. 44, 254-261, https://doi.org/10.4314/sajas.v44i3.7

Shen Y.B., Piao X.S., Kim S.W., Wang L., Liu P., 2010. The effects of berberine on the magnitude of the acute inflammatory response induced by Escherichia coli lipopolysaccharide in broiler chickens. Poult. Sci. 89, 13-19, https://doi. org/10.3382/ps.2009-00243

Shokrollahi B., Sharifi B., 2018. Effect of Nigella sativa seeds on growth performance, blood parameters, carcass quality and antibody production in Japanese quails. J. Livest. Sci. 9, 56-64

Soliman E.S., Hamad R.T., Ahmed A., 2017. Prophylactic and immune modulatory influences of Nigella sativa Linn. in broilers exposed to biological challenge. Vet. World 10, 1447-1455, https://doi.org/10.14202/vetworld.2017.1447-1455

Tangney C.C., Rasmussen H.E., 2013. Polyphenols, inflammation and cardiovascular disease. Curr. Atheroscler. Rep. 15, 324, https://doi.org/10.1007/s11883-013-0324-x

Toghyani M., Toghyani M., Gheisari A., Ghalamkari G., Mohammadrezaei M., 2010. Growth performance, serum biochemistry and blood hematology of broiler chicks fed different levels of black seed (Nigella sativa) and peppermint (Mentha piperita). Livest. Sci. 129, 173-178, https://doi. org/10.1016/j.livsci.2010.01.021

Torki M., Sedgh-Gooya S., Mohammadi H., 2018. Effects of adding essential oils of rosemary, dill and chicory extract to diets on performance, egg quality and some blood parameters of laying hens subjected to heat stress. J. Appl. Anim. Res. 46, 1118-1126., https://doi.org/10.1080/09712119.2018.1473254

Türk G., Çeribaşı A.O., Şimşek Ü.G. et al., 2016. Dietary rosemary oil alleviates heat stress-induced structural and functional damage through lipid peroxidation in the testes of growing Japanese quail. Anim. Reprod. Sci. 164, 133-143, https://doi. org/10.1016/j.anireprosci.2015.11.021

Tülüce Y., Özkol H., Söğüt B., Çelik I., 2009. Effects of Nigella sativa on lipid peroxidation and reduced glutathione levels in erythrocytes of broiler chickens. Cell Membr. Free Radic. Res. 1(3), 95-99

Valenzuela A., Sanhueza J., Nieto S., 2004. Cholesterol oxidized products in foods: potential health hazards and the role of antioxidants in prevention. Grasas Aceites 55, 312-320, https:// doi.org/10.3989/gya.2004.v55.i3.194

Yazan L.S., Ng W.K., Al-Naqeeb G., Ismail M., 2009. Cytotoxicity of thymoquinone (TQ) from Nigella sativa towards human cervical carcinoma cell (HeLa). J. Pharm. Res, 2, 585-589

Yildirim B.A., Tunc M.A., Gül M., Yildirim F., Yıldız A., 2018. The effect of Rosemary (Rosmarinus officinalis L.) extract supplemented into broiler diets, on performance and blood parameters. GSC Biol. Pharmaceut. Sci. 2(3), 001-009, https://doi. org/10.30574/gscbps.2018.2.3.0057 